\title{
Internet Culture Influence and Strategy for Political
}

\section{and Ideological Education}

\author{
Li Gao \\ Dept. of Automobile Engineering, Dezhou University \\ Dezhou 253023, Shandong, China \\ E-mail: dzxygl@126.com
}

\begin{abstract}
As Internet appears and develops, it creates a totally new network environment. Internet culture has become an important section of college students' daily life. The paper analyzes the influence of internet culture on political and ideological education, and expounds the ways to do the ideological and political work for college students via network
\end{abstract}

Keywords: Internet culture, College students, Political and ideological education

21 st century is a networked and digitized high-technology age, the information revolution cored by Internet has entered university campus, whose popularization and widely-use has broaden the horizon of the students and brought convenience to their daily life and study. In spite of that, its harmful aspects have hugely influenced the students on their thought, values and behaviors which adds much more difficulty to the ideological and political education. It's an important task, which all the educators have to face, to intensify the exploration of university students' ideological and political education and educate the students according to the features of the Internet.

\section{Challenge that the feature of Internet makes for college students' ideological and political education}

The feature of Internet makes it a challenge for the educators to use the Internet to carry out educational work. We should well-know them so as to well-control and develop them, then devise scientific, plentiful, ideological and aim-focused educating plan.

1.1 It is open. The Internet connects all the corners on earth, it does not influenced by habitant area, race, sex, age, religious belief, political position, value and custom. People can surf the Internet freely. Up till now, Internet has permeated every corner of university campus, university is no more enclosed study place, using Internet to gain knowledge, send massages, and communicate emotion has popularized among more and more students. Due to the openness of Internet information, tremendous and various information pass to the students directly which in return impact the thoughts of students and the traditional ideological education of the educators.

1.2 It is anonymous, which complicates the thoughts of the Internet-surfing students. Internet information exchange is for sole person and computer, people conceal their true identity and distribute responsibility-lacking information. University students usually speak according to their own values and behavior principles. This kind of contact and communication leads to the tendency of complication of the students' traditional values, sense of self-discipline, legal awareness, value tendency and interpersonal relationship. Internet places the students onto a no-barrier and super-time-and -space information exchange age.

1.3 It is widely-used. Campus internet has become important, basic facility for teaching, scientific, research and management. Its wideness not only shows in that it broaden the students' communication space but also in that many students have their own computers, through the Internet, they can distribute information, chat, create, study the problem in which the show common interest in their dormitories. The wideness of Internet makes the students accept all kinds of information brought by the Internet culture more directly and frequently.

1.4 Internet has changed the traditional education style. The internet age has changed the passively-accept learning style, university students become more initiative, they can make use of the computer to choose and exchange information freely, master some sort of knowledge more than teachers do; They can visit experts and intellectual with no necessity to step out of the campus; They can refer to the data, explore the unknown fields and enrich knowledge. The internet is able to spread various information necessary to the students, able to analyze and integrate it and make it to be used to the utmost. 


\section{Opportunity Network generated for college students' ideological and political education}

2.1 Network enables college's ideological and political work to break the limitations of time and space. Due to time and space limitations, traditional ideological and political education, which is usually conducted by politics study and having heart-to-hearts, has a very scant coverage. The development of network allows the ideological and political education to make a breakthrough in time and space. Like a renowned professor having his class, thousands of people being his audience at the same time, he can utilize one method to resolve the ideological and psychological problems of many people at one time, making sure the valid information is broadly propagated.

2.2 The development of network can help to improve the efficiency of ideological and political work and update the management. As a new method of communication, network possesses the characteristics of rapidity and high efficiency in informational transmission. As the spread of network in colleges, many management work can be done online, such as online curriculum catalogue, teaching plan, employment information's release, sport's and living information. By Internet, these all can be rapidly passed to students. Particularly, the time content and form of school's ideological and political work can be systematically and regularly released online, so students can always browse and make options.

2.3 Network is a significant position to carry out ideological and political work. The formation of moral value system is basically originated in the ethnical mass media. Now when students can freely obtain information about ethnic groups online and communicate with people of different languages, the duality between the diversity of composite culture and cultural characteristics of ethnicity is inevitably showed in the internationalization of ideological and political work. If colleges can do their ideological and political work effectively, they can properly lead students to obtain the advanced culture and good moral characters from various ethnic groups. Meanwhile, it allows students to expand their horizons.

2.4 Network can enrich the methods of colleges' ideological and political work and fulfill students' various needs. Ideological and political work can be integrated into the various forms of network to provide service to college students' life study and work. Meanwhile, a correct outlook of life and value is permeated. Therefore, college's ideological and political work should make the most of Network to provide the most comprehensive service to students and make their ideological and political work more distinctive.

\section{Ways to do the ideological and political work for college students via network}

With the spread and wide application of the network, great challenges as well as chances have occurred to teachers in their ideological political work, which requires teachers to seek new ways to do the ideological and political work actively with high responsibility and composure.

3.1 Set up school information media which is of importance to do the ideological and political work for college students. Nowadays every university has its own school network. However, the applications of the network are mainly limited to school publicity, such as introductions of the school's history, size, major, scientific research, information about sitting postgraduate entrance exam. Some universities merely use it for departments information communication and materials consultation. And the functions of network is far from being developed. Under the research of the author, the school-developed cyber information has few things to do with the students except for some rules and regulations, reports about student activities. Students often communicate with each other in the BBS. However, school administrations or teachers seldom talk about issues publicly. As a result, fewer students access the school net. Under such circumstances, school administration of network should work together with other departments to develop network information which is delighted to hear and see: firstly, establishing a "online school" which provides students with information about current affair, study guidance, talent consultation and so on. Besides they can put good reports, lectures, student activities as well as social practice on the net so that students can get a better understanding of national conditions, society and receive good education; secondly, ideological and political workers should join the construction of the network actively, send valid information on the net on regular, intensify the network controllability and take full advantage of the network to propel the ideological and political education work.

3.2 Set up complete school network media system. Building up a qualified online information publicity team, fighting against the negative information in time and seize the net position actively. Firstly, setting a specialized ideological and political studio online, appealing political assistants and skeleton students to draw the students' attention to extracurricular activities, abundant school culture and positive, active and healthy ideological position. Secondly, carrying out network activities which are rich in content and varied in style such as online research. it is much more direct and accurate to know how the students think and do the ideological and political work with a definite goal. Teachers and students can talk about the hot spots, difficult topics online without 
limitations of a face-to-face talk and also it can be considered to be another communicating bridge between the school administration and students.

3.3 Try to combine internet education and service function, close the relationship between students and healthy website, WebPages, increase the students' acceptance of ideological and political contents. Thus, the ideological and political teachers should do an follows: Firstly, concern the students' network psychology, instruct properly as to make the students able to identify network society and virtual society. Their resistance against unhealthy culture tide will increase correspondingly. Secondly, publish the content and focus about the activities which the students concern most. Students can get a sketch of that timely. Thirdly, establish career information web, publish job information, get the students acquaint themselves with the demand of personnel market so that they can find the right job-seeking direction, form right working attitude and find their identity and integrity, realize the value of life.

3.4 Intensify the internet management; organize a powerful, ideological and political educator team. First, train the ideological and political educator team purposely, designedly and organizationally. In addition, be familiar with the internet features; realize its function in ideological and political education. Increase the educators' technological quality and internet application awareness. Also, we can take measures to control the irresponsible argument on the Internet. For instance, without personal ID and password registered in school, students will fail to $\log$ on to the Internet. Thus negative information can be effectively controlled.

\section{References}

J. Cho, H. G. Zuniga, H. Rojas \& D. V. Shah. (2003). Beyond access: The digital divide and internet uses and gratifications, IT \& Society. 1 (4), pp. 46-72.

Wang, Dengfeng. (2001). Internet and the ideological and political education in colleges: Opportunities, Challenges, Innovation. Ideological and Political Education Tribune, (2).

Y. S. Hsu, Y. J. Cheng \& G. F. Chou. (2003). Internet use in a senior high school: A case study, Innovations in Education and Teaching International., 40 (4), pp. 356-368. 